\title{
Epigenetika helburu duten sendagaiak
}

\section{(Drugs targeting epigenetics)}

\author{
Oihane Martínez-Peula*1, Guadalupe Rivero Calera ${ }^{1,2}$ \\ ${ }^{1}$ Farmakologia Saila, Medikuntza eta Erizantza Fakultatea, Leioa (UPV/EHU) \\ ${ }^{2}$ Biocruces Bizkaia Osasun Ikerketa Institutua, Barakaldo, Bizkaia, Espainia \\ eta CIBERSAM (Centro de Investigación Biomédica en Red de Salud Mental)
}

\begin{abstract}
LABURPENA: Epigenetika hitzak DNA-sekuentzia aldatu gabe aktibitate genetikoan gertatzen den edozein aldaketari egiten dio erreferentzia. Faktore ez-genetikoek (hala nola, infekzioak eta farmakoak) aldaketa epigenetikoak eragin ditzakete, gure genoma osotik zein gene adieraziko diren eta zein ez erabakiz. Hortaz, epigenetika genetikaren eta inguruko faktoreen eta esperientzien arteko lokailua da. Garai erabakigarrietan (garapen fetalean, haurtzaro goiztiarrean eta nerabetasunean) eraginez, faktore ez-genetikoek gure epigenoma ezarriko lukete, deskribatu izan diren 3 mekanismoren bidez: DNAren metilazioa, histonen itzulpen osteko aldaketak eta RNA ez-kodetzaileen eragina. Azken hamarkadetan, epigenetikaren inguruko ikerketa ugari egin dira; gehien aztertu den mekanismo epigenetikoa itzulpen osteko histonen azetilazioa izan da. Azetilazio-asaldurak hainbat gaixotasunen garapenarekin erlazionatu dira. Horren adibiderik aipagarriena minbizia izan da. Horretan oinarrituz, histonen deazetilasen inhibitzaileak (HDACi) minbiziaren kontrako tratamendu gisa postulatu ziren. Gaur egun, lau HDACi daude onartuta minbizi-mota ezberdinen aurkako tratamendurako, eta 20 baino gehiago fase klinikoan ebaluatzen ari dira. HDACi-ek minbizian duten eraginkortasunak beste gaixotasun batzuetan aztertzeko aukera eman du. Gaixotasun neuroendekatzaile eta psikiatrikoen konplexutasuna eta tratamendu eraginkorren falta dela eta, HDACi-ak terapia potentzial interesgarri bihurtu dira. HDACi-ek eragile neurobabesle gisa joka dezaketenez, Huntingtonen eta Parkinsonen gaixotasunetan duten eraginkortasuna aztertzen ari da. Asaldura bipolarrean eta eskizofrenian ere aurrera doa HDACi-en ikerketa.
\end{abstract}

HITZ GAKOAK: Epigenetika, mekanismo epigenetikoak, COVID-19a, histonen deazetilasen inhibitzaileak (HDACi), minbizia, Huntingtonen gaixotasuna, Parkinsonen gaixotasuna, asaldura bipolarra, eskizofrenia.

\begin{abstract}
Epigenetics refers to any change in genetic activity without altering DNA sequence. Non-genetic factors (i.e. infections and drugs) may cause epigenetic alterations throughout our genome, indicating which gene will be expressed and which one will not. Therefore, epigenetics is the linker between genetics and environmental factors and experiences. Exposure to non-genetic factors at crucial stages of development (fetal development, early childhood and adolescence), would establish our epigenome through 3 mechanisms: DNA methylation, post-translational histone modifications and non-coding RNA. There have been many studies in the field of epigenetics in the last decades, the most studied epigenetic mechanism being post-translational histone acetylation. Alterations on histone acetylation pattern have been related to the development of many diseases. The most notable example is cancer. Based on this, histone deacetylase inhibitors (HDACi) became new targets in oncological therapy. Nowadays, four HDACi are approved for the treatment of different types of cancer, and more than 20 HDACi are being evaluated in clinical phase. The efficacy of HDACi against cancer has leveraged the study of HDACi in other diseases. Due to the complexity and the lack of effective treatment for neurological and psychiatric disorders, HDACi drugs have become an interesting potential therapy. Due to neuroprotective properties of HDACi agents, their effectiveness against Huntington's and Parkinson's diseases is being evaluated. HDACi research around bipolar disorder and schizophrenia is also moving forward.
\end{abstract}

KEYWORDS: Epigenetics, epigenetic mechanisms, COVID-19, histone deacetylase inhibitors (HDACi), cancer, Huntington's disease, Parkinson's disease, bipolar disorder, schizophrenia.

* Harremanetan jartzeko / Corresponding author: Oihane Martinez Peula. Farmakologia Saila, Medikuntza eta Erizaintza Fakultatea, Euskal Herriko Unibertsitatea, Sarriena auzoa z/g, 48940, Leioa. - oihane.martinez@ehu.eus - https://orcid. org/0000-0003-0798-7103

Nola aipatu / How to cite: Martínez-Peula, Oihane; Rivero Calera, Guadalupe (2021). «Epigenetika helburu duten sendagaiak». Ekaia, 40, 2021, 11-31. (https://doi.org/10.1387/ekaia.22188).

Jasotze-data: 2020, urriak 23; Onartze-data: 2021, otsailak 2.

ISSN 0214-9753 - eISSN 2444-3581 / (c) 2021 UPV/EHU

(c) (i) (-) $\odot$ Lan hau Creative Commons Aitortu-EzKomertziala-LanEratorririkGabe 4.0 Nazioartekoa

(c) lizentzia baten mende dago 


\section{SARRERA}

Epigenetika terminoa zientziaren arlora mugatuta dagoela dirudien arren, gure eguneroko bizitzan ikus dezakegu. Epigenetika gizabanako baten fenotipoa finkatzen duen prozesuetako bat da. Hala, genetikoki berdinak diren bikietan, fenotipoa ezberdina da. Horrelako kasuak nonahi ikus daitezke, nahiz eta biki horiek familia berean hazi. Fenotipoak gaixotasunak pairatzeko arriskuan eragin dezake, eta, gainera, urteetan zehar edota inguruko faktoreen mende alda daiteke. Adibidez, biki horietako batentzat eskola-garaia zailagoa izan daiteke, eta horrek haren haurtzaroa haurridearena baino gogorragoa bihurtu. Umetan izandako arazo horiek heldutasunean alkoholismoa, beste droga batzuen kontsumoa edota gaixotasun psikiatrikoak pairatzeko arriskua handitu dezakete [1]. Beste bikiaren haurtzaroa, aldiz, zoriontsua izan daiteke, baina haren nutrizio-ohiturak batere osasuntsuak ez badira, nagusitan obesitatea, diabetesa edota arazo kardiobaskularrak garatzeko arrisku handiagoa izango du [2]. Zergatik? Gehienok haien bizimoduarengatik eta bizi-esperientziengatik dela esango genuke, eta gure bizimodu eta gure esperientzia goiztiarrek eragin iraunkor bat izan dezaketela ondorioztatuko. Baina osasun-zientzietan aritzen garenoi fenomeno horren oinarri biologikoa interesatzen zaigu. Bikien kode genetikoak berdinak dira; beraz, genomak ere ez dio galdera horri erantzungo. Gaixotasun horiek pairatzeko arriskuaren jatorria edota zergatia azaltzeko, «genomaren gainean» dagoena ulertu behar da; epigenoma, hain zuzen ere. Izan ere, «epi» aurrizki grekoak gainetik esan nahi $\mathrm{du}$; epigenoma, beraz, genomaren gainetik dagoena izango litzateke. Berrikuspen honetan azalduko den bezala, genetikoak ez diren faktore batzuek epigenetika alda dezakete, gure genomaren zein gene aktibatu edo isiltzen den erabakiz, hau da, gure geneen adierazpena erregulatuz. Modu horretan, mekanismo epigenetikoek gure fenotipoa, gaixotasunen agerpena barne, kontrolatuko lukete. Bigarren atal batean, mekanismo epigenetiko horiek modu onuragarrian aldatzen dituzten farmakoen bila egin diren aurrerakuntzak berrikusiko dira.

\section{ZELULAREN NUKLEOARI BEGIRA: ZER DA EPIGENETIKA?}

Genetikak genotipoa finkatzen du; fenotipoa zehaztearen erantzule bat, aldiz, epigenetika da. Baina nola finkatu ahal dituzte aldaketa epigenetiko iraunkorrak faktore ez-genetikoek? Gure material genetikoaren egiturari eraginez. Epigenetikak ez du DNAren sekuentzia aldatzen, aktibitate genetikoa baizik. Hori ulertzeko, DNA zelula eukariotoen nukleoan kromatina izeneko egituran dagoela ekarri behar dugu gogora. Kromatinak zelularen funtzionaltasuna bermatzeko informazio genetikoaren antolakuntza espaziala aldatzen du, eta geneen adierazpenean berebiziko garrantzia du. 


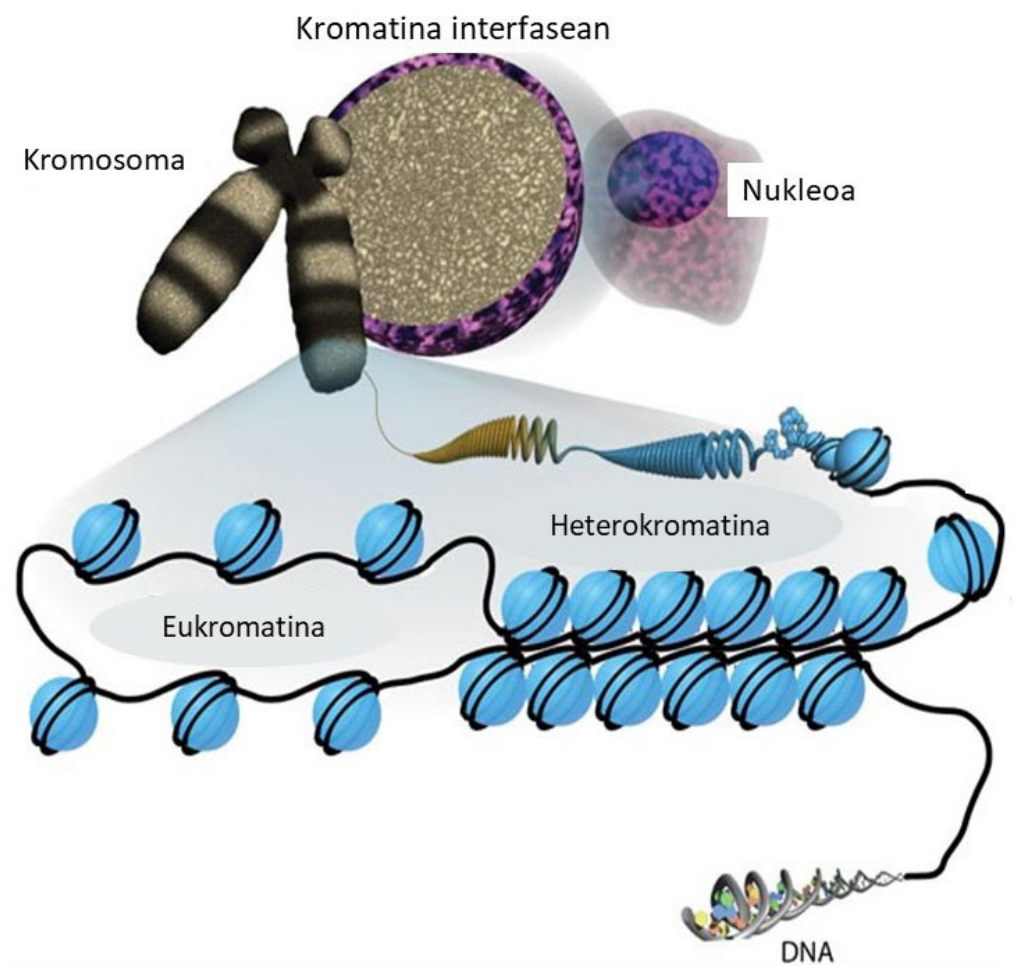

1. irudia. Kromatinaren antolaketa zelula eukariotoetan. DNA zelula eukariotoen nukleoan kromatina izeneko egituran antolatzen da. Bertan, DNAren haria histona izeneko oktameroen inguruan kiribilkatuta dago nukleosomen katea osatuz. Kromatinaren deskiribiltzeak nukleosomak banatzen ditu DNAren eskuragarritasuna handituz (eukromatina) eta transkripzio-prozesua ahalbidetuz. Irudi hau Wikipediatik hartu eta eraldatu izan da, Creative Commons Attribution (CC BY 3.0) lizentziapean [3].

Kromatinaren oinarrizko unitatea nukleosoma da (1. irudiko bola urdinak). Nukleosoma bakoitza histona-oktamero batez eta histona horren inguruan kiribilkatuta dagoen 147 base-pare dituen DNAren zatiaz osatuta dago. Oktamero horrek H2A, H2B, H3 eta $\mathrm{H} 4$ histonen bi kopia ditu. Mekanismo epigenetikoek nukleosomen kondentsazio-maila kontrolatzen dute, eta ondorioz, kromatinaren eskuragarritasuna aldatzen dute. Hori dela eta, kromatina bi egoeraren artean dagoela esaten da: inaktiboaren (heterokromatina) eta aktiboaren (eukromatina) artean. Kondentsatuta dagoenean, hau da, transkripzioa ahalbidetzen ez duenean, inaktibo dago. Geneen transkripzioa ahalbidetzen denean, aldiz, egoera aktiboan dago (1. irudia). Geneen erregulazio epigenetikoa 
DNAren metilazioz edota histonen itzulpen osteko aldaketen bidez gerta daiteke. Histonen N-terminaleko aminoazido hondarretan aldaketa kobalenteak gertatzen dira. Espezie gehienetan $\mathrm{H} 3$ eta $\mathrm{H} 4$ histonek itzulpen osteko aldaketa ezberdinak pairatu ahal dituzte: azetilazioa lisina hondar ezberdinetan, metilazioa arginina eta lisinetan, eta fosforilazioa serina eta treoninetan. Horietatik, epigenetikaren arloan, metilazioa eta azetilazioa ikertu dira gehien [4].

Bai DNAren metilazioak, bai histonen itzulpen osteko aldaketek ezinbesteko garrantzia dute geneen adierazpenaren erregulazioan eta, beraz, haren azterketa beharrezkoa da mekanismo horien konplexutasunaz jabetzeko.

\subsection{DNA-ren metilazioa}

DNAren katean gertatzen den aldaketa nagusia metilazioa da. Metilazioa DNAren zitosinaren 5. karbonoan gerta daiteke, eta DNA-metiltransferasek (DNMT) katalizatzen dute; gehienetan, geneen transkripzioa erreprimitzen du [4]. Metilazio-prozesu horri buruzko lehen ikerketek geneen erregulazioarekin eta zelulen diferentziazioarekin erlazionatu zuten. Ugaztunetan, loci espezifikoetan gertatzen den DNAren metilazioa aita eta amaren aleloen adierazpen bereizgarrirako ezinbestekoa da; X kromosomaren inaktibaziorako, esaterako. Gainera, enbriogenesian zehar aldaketa hori nahiko dinamikoa da [5]. Garapenaren faseak behin igarota, DNAren metilazio-prozesua epe luzerako transkripzioaren errepresioarekin erlazionatzen da. Hala ere, mekanismo hori ez da guztiz argitu eta DNAren metilazioak geneen adierazpenari nola eragin diezaiokeen aztertzen duten ikerketetan emaitza kontraesankorrak lortu dira [6].

\subsection{Histonen metilazioa}

Histonen metilazio entzimatikoa histona-metiltransferasek (HMT) katalizatzen du. Gizakietan, lisina- edo arginina-hondarrekiko espezifikoak diren 50 HMT ezberdin baino gehiago identifikatu dira. HMTek metilo talde baten, biren edo hiruren eransketa katalizatu ahal dute. Aminoazido-hondarraren arabera eta metilazio-mailaren arabera, metilazioaren ondorioak ezberdinak izango dira. H3 histonaren metilazioa 4. edo 79. lisinan gertatu ondoren, geneen transkripzioa aktibatuko da. Aldiz, metilazioa 9. edo 27. lisinan gertatzen bada, transkripzioa inaktibatuko da [4].

Histonen metilazioa ez da behin betiko aldaketa bat. Izan ere, histonademetilasek (HDM) metilo taldeen askapena katalizatzen dute. Entzima horien espezifikotasuna metilazio-mailaren eta metilatu den aminoazido hondarraren araberakoa izango da [4]. 
Epigenetika helburu duten sendagaiak

\subsection{Histonen azetilazioa}

Azetilazioa histonen itzulpen osteko aldaketen artean ikertuenetariko bat da. Histonen azetilazioa histona-azetiltransferasek (HATek) katalizatzen dute. Albo-katean azetilo taldea sartzean, kromatinak egitura irekia hartzen du, eta transkripzioaren handipena bultzatzen du (2. irudia) [4].

TRANSKRIPZIOAREN INAKTIBAZIOA
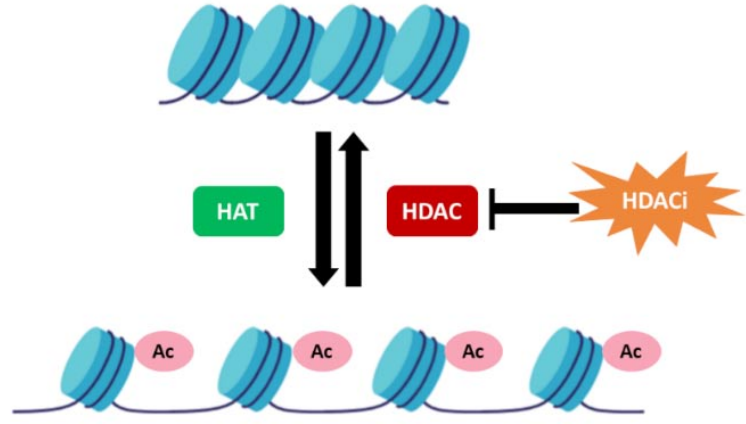

TRANSKRIPZIOAREN AKTIBAZIOA

2. irudia. Histonen azetilazio eta deazetilazioaren ondoriozko eraginak transkripzioan. HAT: histona-azetiltransferasa; HDAC: histona-deazetilasa; HDACi: histona-deazetilasen inhibitzailea; Ac: azetiloa.

Azetilazioaren kontrako prozesua, hau da, deazetilazioa, histonen deazetilasen (HDAC) bidez gertatzen da, eta geneen adierazpenaren murrizketarekin erlazionatzen da. Entzima horien lisina-hondar ezberdinekiko espezifikotasuna ez da guztiz ezagutzen [4]. Egun arte, 18 HDAC isoforma karakterizatu dira, eta 4 klasetan sailkatzen dira; I, II, III eta IV klaseetan, hain zuzen. Haien inhibizio farmakologikorako, garrantzitsua da I, II eta IV klaseak zink-menpekoak direla ezagutzea. I klaseak HDAC1, 2, 3 eta 8 barneratzen ditu, II klasean HDAC4, 5, 6, 7, eta 9, eta IV klasean soilik HDAC11. III klasea entzimatikoki eta egituraren aldetik ezberdina da, eta sirtuina 1, 2, 3, 4, 5, 6 eta 7az osatuta dago [7]. HDAC entzimen funtzio nagusia histonen deazetilazioa nukleoan katalizatzea den arren, pentsatzen da beste hainbat funtzio egin ditzaketela beren kokapen azpizelularraren arabera [8]. Gainera, lehen aipatu bezala, mekanismo epigenetikoak zelula espezifikoak dira. Espezifikotasun hori, beste mekanismoen artean, zelula bakoitzak adierazten dituen HDAC klasearen eta isoforma espezifikoen bidez lor daiteke. Adibidez, garuneko zelula neuronalak eta glialak banatu izan direnean, HDAC adierazpena ezberdina dela aurkitu da [8]. 


\section{EPIGENETIKA ETA GAIXOTASUNEN GARAPENA}

Epigenetikak gaixotasunen garapenean eragina izan dezakeela proposatu zuen lehen lanetako bat Suediako herri bati buruzko ikerketa epidemiologikoa izan zen [9]. Herri horretako artxiboetan, jaiotzari eta heriotzari buruzko informazioaz gain, beste datu sozioekonomiko batzuk ere jasotzen ziren, hala nola goseteak eta uzta txarrak. Ikerketa horren hasierako helburua zen elikadura-ohituren eta osasunaren arteko erlazioa finkatzea. Datuetatik abiatuta, belaunaldi batek izandako dietak (garaiko gosete eta uzta txarrengatik txarra izan zitekeena) belaunaldiko gizabanakoen bizi-itxaropena baldintza zezakeela ikusi zuten ikertzaileek. Baina haientzat, belaunaldi horrek pairatutakoak seme-alaben edota biloben bizi-itxaropenean ere eragina zuela behatzea izan zen harrigarriena. Gainera, nutrizio-gabeziak garapeneko garai garrantzitsuetan gertatzen baziren, bilobengan zituzten ondorioak nabarmenagoak ziren. Geroago egindako ikerketek faktore ez-genetikoen eraginaren garrantzia giza garapenaren hiru unetan finkatu dute: garapen fetalean, haurtzaro goiztiarrean eta nerabetasunean. Hortaz, garapenaren une erabakigarrietan zenbait ingurumen-faktoreren eraginpean egoteak gaixotasunekiko sentikorrago bihurtuko gintuzke, eta faktore horiek eragindako sentikortasun hori gure ondorengoei pasatzeko arriskua egon daiteke [9].

Ikerketak egin ahala, ingurumen-faktore ezberdinak identifikatu dira, hala nola nutrizio-egoera, gai kimikoekiko esposizioa, estresa, farmakoak eta infekzioak. Faktore horiek gaixotasunen garapenean izan ahal duten eragina mekanismo epigenetikoen bidez azal daiteke: DNAren metilazioa, histonen itzulpen osteko aldaketak eta RNA ez-kodetzaileen eragina [10].

Mekanismo epigenetikoen asaldurak gaixotasunetan maiz deskribatu dira. Adibidez, minbizian aldaketa epigenetiko iraunkorrak aurkitu dira [11]. Obesitatean eta diabetesean ere, mekanismo epigenetiko bereizgarriak identifikatzen ari dira [10]. Asaldura neurologikoetan eta adinarekin erlazionatuta dauden Alzheimerren eta Parkinsonen gaixotasunetan ere aztertzen ari da mekanismo epigenetikoen garrantzia $[12,13]$. Aurkikuntza horiek epigenetikak gaixotasunen diagnostikoan, pronostikoan eta terapian izan dezakeen garrantzia azaleratu dute.

Epigenetikaren eragina gaixotasun psikiatrikoetan ere gaurkotasun-gaia da. Izan ere, gaixotasun psikiatrikoak konplexuak dira, eta haien etiopatogenia ez dago guztiz argi. Eskizofreniaren kasuan, esaterako, heredagarritasun-tasa handia da. Herentzia genetikoak gaixotasuna pairatzeko arriskua handitzen du, baina ez da nahikoa gaixotasuna garatzeko [14]. Azken ikerketek faktore ez-genetikoek ere eskizofrenia garatzeko arriskua handitzen dutela azpimarratu dute, eta berriro ere, mekanismo epigenetikoak fenomeno horren eragile gisa postulatu dira [15]. 


\section{ALDAKETA EPIGENETIKOAK ETA COVID-19 BIRUSA}

Bizi dugun egoerari dagokionez, epigenetikaren eta COVID-19 birusaren arteko bi norabideko erlazioa aipa dezakegu. Alde batetik, koronabirus eta influenza birusak zelula ostalarien sekuentzia genetikoa aldatzeko gai ez diren arren, aldaketa epigenetikoen bitartez, infekzioaren hedapena lor dezakete [16]. Mekanismo epigenetiko hori ez da guztiz argitu, baina azken aldiko ikerketa batean H5N1ak (hegazti-gripearen birus-anduia) eta MERS-CoVak (Ekialde Ertaineko arnas sindromearen koronabirusa) DNAren metilazioaren bidez antigenoa aurkezten duten molekulen adierazpena murrizten dutela proposatu da [17].

Bestalde, gaixotasunaren pronostikoan erabakigarriak diren faktore ugarik mekanismo epigenetikoen bidez gure erantzun immunea eta kutsakortasuna alda ditzakete. Erantzun immuneari dagokionez, adinarekin batera epigenoman gertatzen diren aldaketek sistema immunea ahuldu dezaketela ikusi da, T zelulen funtzionaltasunean, zitokinen suntsipenenean eta patogenoen ezagutza-patroietan eraginez [18]. Kutsakortasunari begira, COVID-19 birusak zelulak infektatzeko erabiltzen duen ACE2 entzimaren adierazpen genikoa DNAren metilazioaren bidez erregulatzen dela proposatu berri da [19]. Beste ikerketa batean, DNAren metilazio-patroi hori sexuaren eta adinaren arabera aldatzen dela determinatu da, eta ACE2 genearen metilazio-maila pazienteen arriskua aurreikusteko markatzaile gisa proposatu [20].

Datu gehienen arabera, gaixotasun kronikoek ere (lupus eritematosoa, kasu baterako) COVID-19ari erantzuteko moduan izan dezakete eragina. Lupus pazienteetan DNAren metilazio-gutxitze nabarmena dago. DNAren hipometilazioak X kromosomari eragiten dio batez ere; kromosoma horren barruan ACE2 genea kokatzen da. Ikerketa berri batek ACE2 genearen hipometilazioa eta ACE2 entzimaren adierazpen handiagoa aurkitu ditu lupuspazienteen T zeluletan; horren ondorioz, COVID-19 kasu larriagoak gerta daitezkeela proposatu du [19].

\section{POSIBLE AL DA EPIGENETIKA FARMAKOLOGIKOKI MODULATZEA?}

Orain arte azaldutakoaren arabera, gure bizitzan zehar gertatutakoa, pairatutakoa edota erabakitakoa etorkizunean garatuko ditugun gaixotasunen eragile izan daiteke. Horrez gain, amaren sabelean gaudela, gure amari gertatutakoaren ondorioz gure zeluletan aldaketa epigenetiko iraunkorrak ager daitezke, gure bizitzan eragingo dutenak [21, 22]. Beraz, epigenetika belaunaldiz belaunaldi transmititzen diren ezaugarri onuragarri eta kaltegarrien erantzule izan daiteke; horrek ondorio mediko eta etiko larriak 
izan ditzake. Egoera horren aurrean, gure patu epigenetikoa onartu behar al dugu? Molda daiteke epigenetika farmakologikoki? Bai, posible da, eta hori ikertzen duen farmakologiaren atalari farmakoepigenetika deritzo.

Farmakoepigenetika jakintzagai berri honen helburu nagusia terapia epigenetikoa da, hau da, farmakoen bidez gaixotasunekin erlazionatutako aldaketa epigenetikoak saihestea edo tratatzea. Gaur egun, mekanismo epigenetikoetan eragina duten farmako batzuk ikertzen ari dira; adibidez, DNMTen inhibitzaileak edo HMTen inhibitzaileak [23-25]. Baina azken urteetan berebiziko garrantzia hartu dutenak HDAC entzimen inhibitzaileak (HDACi) dira [4].

Histonen lisina-hondarren deazetilazioa leheneratuta histonen hiperazetilazioa eragiten duten konposatuak dira HDACi-ak. Hiperazetilazioak nukleosomaren eta honen inguruan bilduta dagoen DNAren arteko tartea handitzen du. Kromatinaren egituran gertatzen den irekiera horrek geneen hasierako aldea eskura uzten du transkripzioa edo irakurketa izan dadin. Arestian aipatu denez, lau klasetako 18 HDAC daude. HDACi-ek, HDAC isoformekiko espezifikoak izatea baino gehiago, HDAC klasearekiko espezifikotasuna aurkezten dute. Hortaz, HDACi batek HDAC isoforma ezberdin asko inhibi ditzake; ez-espezifikotasun hori eragin onuragarriekin erlaziona daiteke, baina baita kaltegarriekin ere [26].

HDACi batzuk iturri naturaletatik purifikatu dira, eta beste batzuk kimikoki sintetizatu dira. Euren egitura kimikoan oinarrituta, HDACi-ak bost taldetan sailkatzen dira: hidroxamatoak, peptido ziklikoak, kate motzeko gantz azidoak, bentzamidak eta beste jatorriko konposatu batzuk (3. irudia). Hidroxamato-egitura duten HDACi-ak HDAC entzimen zink ioiaren domeinu katalitikoari lotzen zaizkio, eta entzimaren aktibitatea inaktibatzen da. Mekanismo hori dela eta, hidroxamatoek I eta II klaseetako HDACak inhibitzen dituztela uste da. Peptido ziklikoen taldea oso zabala da, eta talde hori osatzen duten HDACi-ek egitura ezberdinak aurkezten dituzte. Egituraren aniztasuna dela eta, talde horretako inhibitzaileek HDAC isoforma ezberdinak espezifikoki inhibitzen dituzte; horrek HDACi farmakoen garapenerako eta ikerkuntzarako talde interesgarria bihurtzen dute. Hala eta guztiz ere, gutxien ikertu den taldea da; peptido ziklikoen adibide ezagunenak apizidina eta romidepsina dira. Kate motzeko gantz azidoen taldeko HDACi ezagunenak azido balproikoa, butiratoa eta fenilbutiratoa dira. Talde honek garrantzi handia dauka neurofarmakologia arloan. Gehienek I eta II klaseko HDAC entzimak inhibitzen dituzte, baina, beste HDACi taldeekin konparatuta, potentzia txikienekoak dira. Potentzia -falta hori zink katioiarekin elkar eragiteko ezgaitasunagatik dela uste da. Bentzamidak, beste HDACi taldeekin konparatuta, erdibizitza luzea eta selektibitate nahikoa aurkezten dute. Izan ere, HDACi berrien ikerkuntzan, talde horretako konposatuek garrantzi handia hartu dute, eta HDAC isoforma espezifikoak inhibitzeko diseinatuak dira. Beste jatorriko konpo- 
satuen artean, III klaseko HDACak inhibitzen dituzten farmakoak daude. Talde horren adibiderik ezagunenak suramina eta nikotinamida dira. Suraminak sirtuina 1 eta 2 inhibitzen ditu; nikotinamidak, ordea, sirtuina 7. Azken horrek, aho bidez administratzen denean, hesi hematoentzefalikoa erraz zeharkatzen du; horregatik bilakatu da neurozientzietan ikertzeko farmako interesgarria [26].

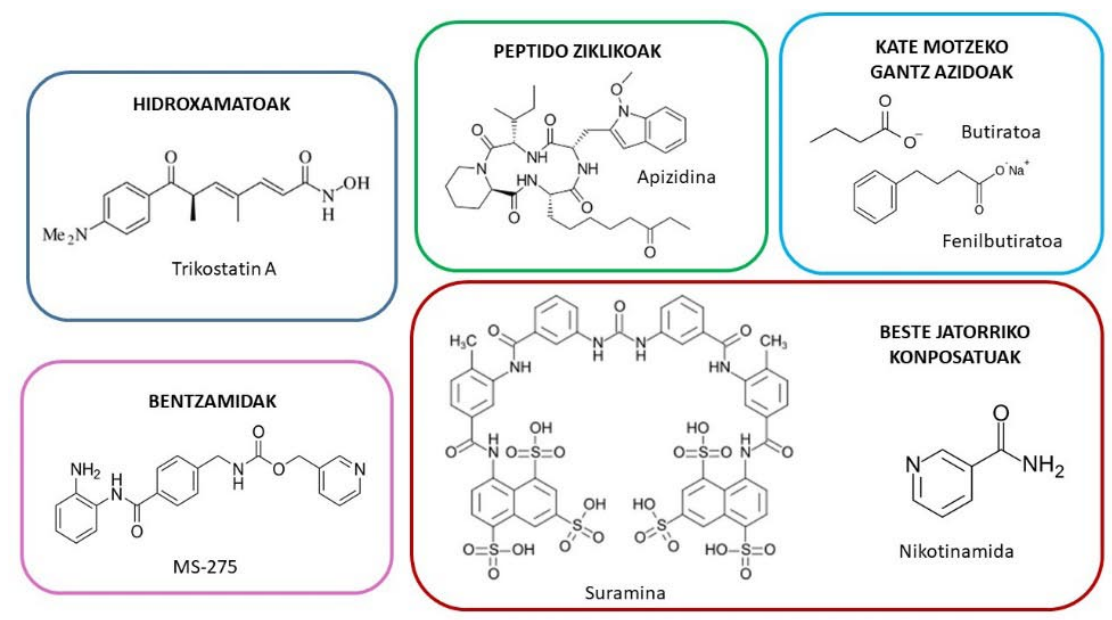

3. irudia. Histonen deazetilasen inhibitzaile (HDACi) motak egitura kimikoaren arabera eta zenbait adibide. HDACi-en egiturak bost taldetan banatzen dira: hidroxamatoak (trikostatin A), peptido ziklikoak (apizidina), kate motzeko gantz azidoak (butiratoa, fenilbutiratoa), bentzamidak (MS-275) eta beste jatorriko konposatu batzuk (suramina eta nikotinamida).

\subsection{Epigenetikan oinarritutako minbiziaren aurkako tratamenduak}

Minbizian aurkitutako lehenengo aldaketa epigenetikoa koloneko minbizi-zelulen DNAren metilazio-mailaren jaitsiera izan zen [27]. Hortik aurrera, ikerketek minbizi-mota ezberdinetan aldaketa epigenetiko bereizgarriak deskribatu dituzte; gehienak histonen azetilazio-asaldurak ziren $[28,29]$. Horrekin batera, HDAC entzimak minbiziaren fase ezberdinetan inplikatuta daudela ikusi da; HDACen maila handiak gaixotasunaren fase terminalarekin erlazionatzen dira [11]. Hori dela eta, HDACi-ak minbizia tratatzeko alternatiba terapeutiko gisa postulatu dira.

2006. urtean, FDAk (Food and Drug Administration) lehenengo HDACi-a onartu zuen, vorinostat-a (SAHA). Farmako horrek I, II eta IV klaseko HDAC entzimen aktibitatea inhibitzen du, eta $T$ zelulen azaleko linfomaren tratamenduan eraginkorra da [30]. Linfoma-mota horren 
aurka, 2009. urtean, FDAk romidepsin farmakoa ere onartu zuen, egitura biziklikoa duen I klaseko HDAC entzimen inhibitzaile selektibo eta potentea dena. Bi urte geroago, romidepsinari beste indikazio bat gehitu zitzaion, $T$ zelulen linfoma periferiko errefraktarioa [31]. 2014. eta 2015. urteetan belinostat eta panobinostat farmakoak onartu ziren: belinostat-a, T zelulen linfoma periferikoaren kontrakoa, eta panobinostat-a, mieloma anizkoitzaren kontrakoa. Gaur egun, 20 HDACi baino gehiagoren eraginkortasun terapeutikoa fase klinikoan ebaluatzen ari da; givinostat-arena, esaterako. Farmako hori, panobinostat-a bezala, mieloma anizkoitzaren aurka eraginkorra izan daiteke, eta II. faseko entseguetan dago. Azido balproikoa ere I eta II. faseko entseguetan ebaluatzen ari da. Kasu honetan, tumore solidoen aurkako tratamendu bezala eraginkorra izan daiteke [32] (1. taula).

1. taula. Minbizian onartuak diren edota entsegu klinikoetan ebaluatzen ari diren HDACi-en adibideak. Taula honetan farmako bakoitzaren izena, egitura kimikoa, farmakoak inhibitzen dituen HDAC entzimen klaseak, eta argitaratutako entsegu klinikoak edota erabilera klinikoa azaltzen dira.

\begin{tabular}{|c|c|c|c|}
\hline Farmakoa & Egitura kimikoa & $\begin{array}{c}\text { Inhibizio } \\
\text { espezifikotasuna }\end{array}$ & $\begin{array}{l}\text { Entsegu klinikoak } \\
\text { eta erabilera }\end{array}$ \\
\hline $\begin{array}{l}\text { Vorinostata } \\
\text { (SAHA) }\end{array}$ & Hidroxamatoa & $\begin{array}{l}\text { I, II } \\
\text { eta IV klaseak }\end{array}$ & $\begin{array}{l}\text { 2006. urtean onartuta } \\
\text { - T zelulen azaleko } \\
\text { linfoma [30] } \\
\text { 2. faseko entseguak: } \\
\text { - Ehun bigunetako } \\
\text { sarkomak [33] } \\
\text { - Leuzemia mieloide } \\
\text { akutua [34] } \\
\text { 1. faseko entseguak: } \\
\text { - Minbizi } \\
\text { gastrointestinala [35] } \\
\text { - Linfoma } \\
\text { folikularra [36] }\end{array}$ \\
\hline Romidepsina & Peptido ziklikoa & I klasea & $\begin{array}{l}\text { 2009. urtean onartuta: } \\
\text { - T zelulen azaleko } \\
\text { linfoma [31] } \\
\text { 2011. urtean onartuta: } \\
\text { - T zelulen linfoma } \\
\text { periferiko } \\
\text { errefraktarioa [31] } \\
\text { 2. faseko entseguak: } \\
\text { - Prostata-minbizia [37] }\end{array}$ \\
\hline
\end{tabular}


Epigenetika helburu duten sendagaiak

\begin{tabular}{l|l|l|l}
\hline Farmakoa & \multicolumn{1}{|c|}{ Egitura kimikoa } & $\begin{array}{c}\text { Inhibizio } \\
\text { espezifikotasuna }\end{array}$ & \multicolumn{1}{c}{$\begin{array}{c}\text { Entsegu klinikoak } \\
\text { eta erabilera }\end{array}$} \\
\hline Belinostata & Hidroxamatoa & $\begin{array}{l}\text { I, II } \\
\text { eta IV klaseak }\end{array}$ & $\begin{array}{c}\text { 2014. urtean onartuta } \\
\text { - T zelulen linfoma } \\
\text { periferikoa[32] }\end{array}$ \\
$\begin{array}{l}\text { 2.faseko entseguak: } \\
- \text { Timoma [38] } \\
\text { - Leuzemia } \\
\text { mieloidea [39] }\end{array}$ \\
\hline Panobinostata
\end{tabular}

Ebaluatzen ari diren HDACi gehienak minbizi hematologikoetan dira eraginkorrak. Tumore solidoen kasuan, HDACi-ak monoterapian eraginkorrak ez direla ikusi da. Horren kausa ez dago argi, baina ikerketa gehienek HDACi-en propietate farmakozinetikoengatik dela proposatzen dute. Gainera, tumoreen ezaugarri heterogeneoak direla eta, HDACi-ak beste farmako antineoplasikoekin batera erabiltzeak aukera hoberena dirudi $[32,46]$. Adibidez, HDACi-ak agente kimioterapikoekin konbina daitezke. Vorinostata, karboplatinoa eta paklitaxela konbinatzen dituen terapia I. faseko entsegu klinikoetan ebaluatu da. Entsegu horietan vorinostatarekin konbinatutako terapiak emaitza onak aurkeztu ditu eta II. faseko entseguetara pasatu da [47]. Minbizi-mota batzuk hormona-mendekoak direnez (ugatz- eta prostata-minbizia, esaterako), terapia hormonala HDACi-ekin konbinatzen saiatu da. Prostata-minbizian HDACi-en monoterapiak ez du 
emaitza onik lortu. Aldiz, fase aurreklinikoan, HDACi bat bikalutamida antiandrogenoarekin konbinatzean, eragin zitotoxikoaren sinergia hauteman da [48, 49].

HDACi-en erabilera hedatu ahala, lehen eragin kaltegarriak ere deskribatu dira. Orain arte, pazienteek pairatu ahal dituzten eragin kaltegarri ohikoenak gastrointestinalak (beherakoa, goragale eta goitikak), odol-asaldurak (tronbozitopenia, neutropenia), anorexia edota nekea dira. Deskribatu den eragin kaltegarririk larriena romidepsinarekin hautemandako toxikotasun kardiakoa (arritmia bentrikularra) da. Izan ere, FDA-k onartu baino lehen, entsegu klinikoetan romidepsina hartu zuten sei gaixo kausa horrengatik hil ziren [32].

Nahiz eta HDACi-ek (monoterapian eta terapia konbinatuetan) minbizia tratatzeko bide berriak ireki dituzten, horiekin batera mugak azaldu dira. HDACi-ekin erlazionaturiko eragin kaltegarriak gainditzeaz gain, minbizi zelulen HDACi-ekiko erresistentzia ere gainditu beharra dago. Beraz, HDACi-etan oinarritutako terapia konbinatuaren eraginak guztiz ezagutzeko, entsegu kliniko handiagoak egitea beharrezkoa da. Gainera, etorkizuneko ikerketak HDACi-en selektibitatea hobetzen zentratuko dira: horien eragina minbizi-zeluletara mugatuko da, eta, ondorioz, zelula ezkantzerigenoetan dituzten eragin kaltegarriak murriztuko $[32,46]$.

\subsection{HDACi-en erabilera beste gaixotasun kronikoetan}

Arestian aipatu denez, erregulazio epigenetikoak prozesu zelular anitzetan parte hartzen du. Zenbait ikerketatan, aldaketa epigenetikoek neuronen garapenean eta plastikotasunean duten garrantzia ikertu da, eta hipoazetilazioa neuroendekapenarekin erlazionatuta dagoela nabarmendu da. Badirudi HDACi-ek eragile neurobabesle gisa joka dezaketela endekapen neuronala leheneratzeko [26, 50]. Hori dela eta, HDACi-ak neuroendekapenezko gaixotasunen eta gaixotasun psikiatrikoen tratamendu gisa postulatu dira [26, 51]. Izan ere, garun-gaixotasunak konplexuak dira, eta batzuen etiopatogenia ez da guztiz ezagutzen. Gainera, gaixotasun horien gaur eguneko farmakoterapia ez da nahikoa. Sintoma batzuk arintzen dituzten arren, beste batzuk okertzen dituzte, edota eragin kaltegarri nabarmenak eragiten dituzte [51].

Hauetako adibide bat, Huntingtonen gaixotasuna da. Funtzio kognitibo eta motorren ezgaitasuna eragiten duen gaixotasun neuroendekatzailea da. Animalia-ereduetan HDACi ezberdinek (A trikostatina (TSA), sodio butiratoa, azido balproikoa, vorinostata edo fenilbutiratoa) ezgaitasun motorraren hobekuntza nabarmena eragiten dutela frogatu da [50]. Fenilbutiratoaren eta balproatoaren eraginkortasuna huntingtondun gaixoetan ere ebaluatu da. I. faseko entsegu kliniko batean, Huntingtonen gaixotasunaren lehenengo sintomak pairatzen hasten diren gaixoetan, fenilbutiratoa segu- 
rua zela eta ondo toleratzen zutela ondorioztatu zen [52]. Azido balproikoa pazienteetan ebaluatu denean, gaixo batzuek pairatzen zuten hiperkinesia mioklonikoaren aurka eraginkorra zela behatu da [53]. Beste ikerketa batzuetan, azido balproikoak huntingtondun gaixoen sintoma psikiatrikoak (hala nola agitazioa, agresibitatea eta halako sintomak) eta depresioa arintzen dituela ikusi da [54].

Huntingtonen gaixotasunaren sintomatologia arintzeko, selisistat farmakoa ere fase klinikoan ebaluatzen ari da. 2010. urtean, Siena Biotech enpresak I. faseko entsegu klinikoa hasi zuen, eta 2013. urtean, II. fasean sartu zen [50]. Izan ere, aleatorizatutako eta itsu bikoitzeko entsegu multizentriko batean selisistata segurua dela eta ondo toleratzen zela ondorioztatu zuten [55].

Huntingtonen gaixotasunaz gain, HDACi-en eraginkortasuna Parkinsonen gaixotasunean ere ikertu da. Parkinsonen gaixotasuna bigarrena da asaldura neuroendekatzaile prebalenteenetan: munduan zehar, 4 milioi paziente baino gehiagok pairatzen dute. Parkinsonen gaixotasuna tratatzeko erabiltzen diren farmakoek sintomak partzialki baino ez dituzte arintzen, eta ez dira endekapen neuronala gelditzeko gai. Azken horri aurre egiteko, HDACi-en artean gehien ikertu den farmakoa azido balproikoa da. Oraindik fase klinikoan ebaluatu ez den arren, entsegu aurreklinikoetan emaitza onak lortu dira. Izan ere, neurona dopaminergikoen zelula-heriotza eredu anitzetan eraginkorra dela ikusi da [56]. Antzera, haren eraginkortasuna animalia-ereduetan ere ikusia da: animalien sintoma motorrak eta ez-motorrak arintzen ditu [26]. Emaitza horiek, MPTParen (neurona dopaminergikoak suntsitzen dituen neurotoxina) administrazioaren ondorioz, Parkinsonen gaixotasunaren animalia-ereduetan lortu ziren. Animalia horietan bost eguneko azido balproikoaren administrazioak neurona dopaminergikoak partzialki babestea lortu zuen. Gainera, animalia-eredu berean, azido balproikoaren tratamenduaren ostean, usaimenaren asaldurak, depresioa, denbora laburreko oroimenaren funtzio-galera eta halako sintoma ez-motorrak hobetu ziren [57].

Gaixotasun neuroendekatzaileetan bezala, gaixotasun psikiatrikoen terapia farmakologikoan HDACi-ak hautagai postulatu dira [51, 58]. Aipatu den bezala, gaixotasun psikiatrikoak tratatzeko erabili ohi den azido balproikoa HDACi-a dela frogatu da [59]. Hau da, gaixotasun psikiatrikoetan erabiltzen den kontzentrazio terapeutikoetan, azido balproikoak HDACak inhibitzen ditu, gene ugariren adierazpena handituz [60]. Badira hamarkada batzuk azido balproikoa asaldura bipolarraren tratamenduan erabiltzen dela, nahiz eta haren ekintza-mekanismoa guztiz argituta ez egon. Gaur egungo hipotesiek azido balproikoak asaldura bipolarrean duen epe luzerako eraginkortasuna HDAC inhibizioarekin lotuta dagoela proposatzen dute. Azido balproikoaren epe laburreko eragin terapeutikoa, aldiz, aspalditik ezaguna den neurotransmisio GABAergikoaren handipenean oinarri- 
tuko litzateke [61]. Horrez gain, ezin da baztertu asaldura bipolarrean erabiltzen diren antidepresiboak, antipsikotikoak eta litio-gatzak epigenetika aldatzeko gai ez izatea. Gainera, azido balproikoaren kasua ez da bakarra. HDACi den sodio butiratoak ere, asaldura bipolarraren animalia-eredu ezberdinetan egindako entsegu aurreklinikoetan, mania eta sintoma depresiboak arintzen ditu [62].

Nahiz eta eskizofreniaren tratamendurako onartutako HDACi-rik ez egon, haien eraginkortasuna entsegu aurrekliniko zein klinikoetan ebaluatzen ari da [63]. Azido balproikoak eskizofrenian izan ahal duen erabilgarritasun potentziala aztertu da; ikerketa gehienek antipsikotikoekin batera administratzean sortzen den eragin sinergikoa ebaluatzen dute. Arratoi adinduetan, azido balproikoa haloperidola administratu baino lehen administratzen zenean, haloperidolaren eragin kaltegarriak arindu eta eragin antipsikotikoa handitzen zen. Animalia adinduetan sinergia hori ikusita, gizabanako eskizofrenikoengan aztertu zen. 20 gizabanako eskizofreniko adinduren (5079 urte) ohiko tratamendu antipsikotikoari azido balproikoa 12 astez gehitu zitzaion. Monoterapiarekin alderatuta, pazienteen psikosi eta depresio sintomatologiaren gutxitze nabariagoa gertatu zen. Azido balproikoaren erabileragatik antzemandako eragin kaltegarri ohikoena sedazioa izan zen [64]. Azido balproiko eta antipsikotikoen terapia konbinatuaren eraginkortasuna psikosi-agerraldi akutuetan ere ebaluatua izan da. 2003an egindako aleatorizatutako entsegu multizentriko batean, ospitalizatutako 200 gizabanako baino gehiagok azido balproikoa eta risperidona edo olanzapina 12 egunean hartu zuten. Tratamendu konbinatuak sintoma positiboak (psikosia, haluzinazioak) hobetu zituen. Gainera, erantzun antipsikotikoa monoterapiarekin baino azkarrago lortu zen [65]. Segurtasunaren aldetik, azido balproikoaren eragin kaltegarriak aspaldi ezagunak dira, asaldura bipolarrean eta epilepsian erabilia izan baita. Aipagarriena, azido balproikoa haurdunengan erabiltzearen debekua da, jaiotako umeengan autismo eta atzerapen kognitiboaren arriskua nabarmenki handitzen baitu [66].

Azido balproikoaz gain, vorinostatak antipsikotikoen eragina potentzia dezakeela ere behatu da. Klozapinaz kronikoki tratatutako eskizofrenia animalia-ereduetan vorinostataren eragina aztertu zen. Vorinostata kronikoki administratu ondoren, klozapinaren eragin antipsikotikoa indartzen zen [67]. Vorinostataren eta klozapinaren arteko eragina ebaluatzeko, I. faseko entsegu kliniko bat martxan jarri zen, baina gaur egun partaide faltagatik geldituta dago [63].

\section{ONDORIOAK}

Azken ikerketek epigenetikaren garrantzia azaleratu dute, gaixotasunen eta epigenetikaren arteko erlazioa identifikatuz. Izan ere, gure bizitzako es- 
perientziek eta inguruneko faktoreek gure etorkizuneko osasun-egoera baldintzatu dezakete, eta eztabaidagarria bada ere, ikerketa batzuek gure seme-alaben osasunean ere eragina izan dezaketela proposatu dute. Faktore ez-genetikoen eragina ekintza-mekanismo epigenetikoetan oinarritzen da: DNAren metilazioa, histonen itzulpen osteko aldaketak eta RNA ez-kodeatzailea. Mekanismo horiek geneen transkripzioan eragiten dute, baina gaixotasunen etiopatogeniaren arloan horien eragina oraindik ez da guztiz argitu. Epigenetika farmakologikoki modula daiteke; horren adibiderik aipagarriena HDACi-ak dira. HDACi batzuk minbiziaren aurka onartuta daude. Haien onarpenaren ondoren eragin kaltegarriak deskribatzen hasi dira; larriena toxikotasun kardiakoa izan da. Minbizian HDACi-en erabilera fase aurreratuagoan dagoen arren, beste gaixotasunetan ere ikertzen ari da, gehienbat HDACi-ak terapia konbinatuetan aztertuz. Farmakoepigenetika gaixotasunen diagnostiko, pronostiko eta tratamendurako etorkizun oparoko eremua izan daiteke. Hurrengo urteetan, merkaturatu diren farmakoen segurtasunaren jarraipena egin beharko da, ikerkuntzaren aldetik farmako espezifikoagoak eta eraginkorragoak bilatzen diren bitartean. Horretarako, gaixotasunen etiopatogeniaren eta epigenetikaren arteko erlazioa zehazki ulertzea ezinbestekoa da.

\section{ESKER ONAK}

Artikulu honek UPV/EHUko doktoratu aurreko laguntza, Eusko Jaurlaritzaren (IT1211-2019) eta Espainiako MINECO (RTI 2018-094414-AI00) proiektuen dirulaguntza jaso du.

\section{BIBLIOGRAFIA}

[1] Teicher, M. H., Samson, J. A., Anderson, C. M., Ohashi, K. 2016. «The effects of childhood maltreatment on brain structure, function and connectivity». Nature Reviews Neuroscience, 17, 652-666.

[2] Loredana Marcovecchio, M., Chiarelli, F. 2013. «Obesity and growth during childhood and puberty». World Review of Nutrition and Dietetics, 106, 135-141.

[3] Chromatin remodeling - Wikipediaren web-orria, https://en.wikipedia.org/ wiki/Chromatin_remodeling (last time accessed: August 31, 2020).

[4] Thomas, E. A. 2017. Histone Posttranslational Modifications in Schizophrenia. DELGADO-MORALES, R. (eds) Neuroepigenomics in Aging and Disease liburuan. Advances in Experimental Medicine and Biology-ren liburu sortan. Springer, cham.

[5] Jung, M., PfeIFer, G. P. 2015. «Aging and DNA methylation». BMC Bio$\log y, \mathbf{1 3}, 1-8$.

[6] Bogdanović, O., Lister, R. 2017. «DNA methylation and the preservation of cell identity». Current Opinion in Genetics and Development, 46, 9-14. 
[7] Seto, E., Yoshida, M. 2014. «Erasers of histone acetylation: The histone deacetylase enzymes». Cold Spring Harbor Perspectives in Biology, 6, 1-26.

[8] Broide RS, Redwine JM, Aftahi N, Young W, Bloom FE, Winrow CJ. 2007. «Distribution of Histone Deacetylases 1-11 in the Rat Brain». Journal of Molecular Neuroscience, 31, 281-287.

[9] Pembrey, M., Saffery, R., Bygren, L. O. LO. 2014. «Human transgenerational responses to early-life experience: potential impact on development, health and biomedical research». Journal of medical genetics, 51, 563-572.

[10] Cavalli, G., Heard, E. 2019. «Advances in epigenetics link genetics to the environment and disease». Nature, 571, 489-499.

[11] Iacobuzio-Donahue, C. A. 2009. «Epigenetic changes in cancer». Annual Review of Pathology: Mechanisms of Disease, 4, 229-249.

[12] QAzI, T. J., QuAn, Z., Mir, A., QING, H. 2018. «Epigenetics in Alzheimer's Disease: Perspective of DNA Methylation». Molecular Neurobiology, 55, 1026-1044.

[13] van Heesbeen, H. J., Smidt, M. P. 2019. «Entanglement of Genetics and Epigenetics in Parkinson's Disease». Frontiers in Neuroscience, 13, 1-15.

[14] IBI, D., GONZÁLEZ-MAESO, J. 2015. «Epigenetic signaling in schizophrenia». Cellular Signalling, 27, 2131-2136.

[15] McDonald, C. 2002. «Early and late environmental risk factors for schizophrenia». Brain Research Reviews, 31, 130-137.

[16] Kuss-Duerkop, S. K., Pyeon, D., Westrich, J. A. 2018. «DNA tumor virus regulation of host dna methylation and its implications for immune evasion and oncogenesis». Viruses, 10, 1-24.

[17] Menachery, V. D., Schäfer, A., Burnum-Johnson, K. E., Mitchell, H. D., Eisfeld, A. J., Walters, K. B., Nicora, C. D., Purvine, S. O., Casey, C. P., Monroe, M. E., Weitz, K. K., Stratton, K. G., Webb-Robertson, B. J. M., Gralinski, L. E., Metz, T. O., Smith, R. D., Waters, K. M., Sims, A. C., KaWAOKA, Y., Baric, R. S. 2018. «MERS-CoV and H5N1 influenza virus antagonize antigen presentation by altering the epigenetic landscape». Proceedings of the National Academy of Sciences of the United States of America, 115, E1012-E1021.

[18] Mueller, A. L., Mcnamara, M. S., Sinclair, D. A. 2020. «Why does COVID-19 disproportionately affect older people?». Aging, 12, 9959-9981.

[19] Sawalha, A. H., ZhaO, M., CoIT, P., Lu, Q. 2020. «Epigenetic dysregulation of ACE2 and interferon-regulated genes might suggest increased COVID-19 susceptibility and severity in lupus patients». Clinical Immunology, 215, 108410.

[20] Corley, M., Ndhlovu, L. 2020. «DNA Methylation Analysis of the COVID-19 host cell receptor, Angiotensin I Converting Enzyme 2 gene (ACE2) in the Respiratory System Reveal Age and Gender Differences». Preprints 2020030295 (doi:10.20944/preprints202003.0295.vl).

[21] BohaceK, J., Mansuy, I. M. 2015. «Molecular insights into transgenerational non-genetic inheritance of acquired behaviours». Nature Reviews Genetics, 16, 641-652. 
[22] HEARD, E., MARTIENSSEN RA. 2012. «Transgenerational epigenetic inheritance: Myths and Mechanisms». Cell, 157, 95-109.

[23] Zhou, Z., LI, H.-Q., LiU, F. 2019. «DNA Methyltransferase Inhibitors and their Therapeutic Potential». Current Topics in Medicinal Chemistry, 18, 2448-2457.

[24] Myasoedova, V. A., Sukhorukov, V., Grechko, A. V., Zhang, D., RoMANENKo, E., OreKhov, V., OreKhov, A. N. 2019. «Inhibitors of DNA Methylation and Histone Deacetylation as Epigenetically Active Drugs for Anticancer Therapy». Current Pharmaceutical Design, 25, 635-641.

[25] CaO, H., Li, L., Deying, Y., Liming, Z., Yewei, X., Yu, B., LiaO, G., Chen, J. 2019. «Recent progress in histone methyltransferase (G9a) inhibitors as anticancer agents». European Journal of Medicinal Chemistry, 179, 537-546.

[26] Harrison, I. F., DeXter, D. T. 2013. «Epigenetic targeting of histone deacetylase: Therapeutic potential in Parkinson's disease?». Pharmacology and Therapeutics, 140, 34-52.

[27] ANDREw P, F., BerT, V. 1983. «Hypomethylation distinguishes genes of some human cancers from their normal counterparts». Nature, 301, 89-92.

[28] Chino. 2009. «Deficient histone acetylation and excessive deacetylase activity as epigenomic marks of prostate cancer cells». International Journal of Oncology, 35, 1417-1422.

[29] Zhao, Y., Fang, X., Wang, Y., Zhang, J., Jiang, S., Liu, Z., Ma, Z., Xu, L., LI, E., ZHANG, K. 2014. "Comprehensive Analysis for Histone Acetylation of Human Colon Cancer Cells Treated with a novel HDAC Inhibitor». $\mathrm{Cu}$ rrent Pharmaceutical Design, 20, 1866-1873.

[30] Mann, B. S., Johnson, J. R., Cohen, M. H., Justice, R., Pazdur, R. 2007. «FDA Approval Summary: Vorinostat for Treatment of Advanced Primary Cutaneous T-Cell Lymphoma». The Oncologist, 12, 1247-1252.

[31] Frye, R., Myers, M., Axelrod, K. C., Ness, E. A., Piekarz, R. L., Bates, S. E., Branch, M. O., Booher, S., Branch, D. 2012. «Romidepsin: A new drug for the treatment of cutaneous T-cell lymphoma». Clinical Journal of Oncology Nursing, 16, 195-204.

[32] LI, Y., SeTO, E. 2016. «HDACs and HDAC inhibitors in cancer development and therapy». Cold Spring Harbor Perspectives in Medicine, 6, 1-34.

[33] Schmitt, T., Mayer-Steinacker, R., Mayer, F., Grünwald, V., Schütte, J., Hartmann, J. T., Kasper, B., Hüsing, J., Hajda, J., Ottawa, G., MeChtersheimer, G., Mikus, G., Burhenne, J., Lehmann, L., Heilig, C. E., Ho, A. D., Egerer, G. 2016. «Vorinostat in refractory soft tissue sarcomasResults of a multi-centre phase II trial of the German Soft Tissue Sarcoma and Bone Tumour Working Group (AIO)». European Journal of Cancer, 64, 74-82.

[34] Schaefer, E. W., Loaiza-Bonilla, A., Juckett, M., DiPersio, J. F., Roy, V., Slack, J., Wu, W., Laumann, K., Espinoza-Delgado, I., Gore, S. D. 2009. «A phase 2 study of vorinostat in acute myeloid leukemia». Haematologica, 94, 1375-1382. 
[35] Doi, T., Hamaguchi, T., Shirao, K., Chin, K., Hatake, K., Noguchi, K., Otsuki, T., Mehta, A., Ohtsu, A. 2013. «Evaluation of safety, pharmacokinetics, and efficacy of vorinostat, a histone deacetylase inhibitor, in the treatment of gastrointestinal (GI) cancer in a phase i clinical trial». International Journal of Clinical Oncology, 18, 87-95.

[36] Watanabe, T., Kato, H., Kobayashi, Y., Yamasaki, S., Morita-Hoshi, Y., Yokoyama, H., Morishima, Y., Ricker, J. L., Otsuki, T., MiyagiMaesima, A., Matsuno, Y., Tobinai, K. 2010. «Potential efficacy of the oral histone deacetylase inhibitor vorinostat in a phase I trial in follicular and mantle cell lymphoma». Cancer Science, 101, 196-200.

[37] Molife, L. R., Attard, G., Fong, P. C., Karavasilis, V., Reid, A. H. M., Patterson, S., Riggs, C. E., Higano, C., Stadler, W. M., McCulloch, W., Dearnaley, D., Parker, C., De Bono, J. S. 2009. «Phase II, two-stage, single-arm trial of the histone deacetylase inhibitor (HDACi) romidepsin in metastatic castration-resistant prostate cancer (CRPC)». Annals of Oncology, 21, 109-113.

[38] Giaccone, G., Rajan, A., Berman, A., Kelly, R. J., Szabo, E., Lopez-Chavez, A., Trepel, J., Lee, M. J., CaO, L., Espinoza-Delgado, I., Spittler, J., LOEHRER, P. J. 2011. «Phase II study of belinostat in patients with recurrent or refractory advanced thymic epithelial tumors». Journal of Clinical Oncology, 29, 2052-2059.

[39] Kirschbaum, M. H., Foon, K. A., Frankel, P., Ruel, C., Pulone, B., TusCANo, J. M., Newman, E. M. 2014. «A phase 2 study of belinostat (PXD101) in patients with relapsed or refractory acute myeloid leukemia or patients over the age of 60 with newly diagnosed acute myeloid leukemia: A California Cancer Consortium Study». Leukemia and Lymphoma, 55, 2301-2304.

[40] Rathkopf, D. E., Picus, J., Hussain, A., Ellard, S., Chi, K. N., Nydam, T., Allen-Freda, E., Mishra, K. K., Porro, M. G., Scher, H. I., Wilding, G. 2013. «A phase 2 study of intravenous panobinostat in patients with castration-resistant prostate cancer». Cancer Chemotherapy and Pharmacology, 72, 537-544.

[41] Morita, S., Oizumi, S., Minami, H., Kitagawa, K., Komatsu, Y., Fujiwara, Y., Inada, M., Yuki, S., KiYota, N., Mitsuma, A., Sawaki, M., TANII, H., KimurA, J., ANDO, Y. 2012. «Phase i dose-escalating study of panobinostat (LBH589) Administered intravenously to Japanese patients with advanced solid tumors». Investigational New Drugs, 30, 1950-1957.

[42] Sharma, S., Witteveen, P. O., Lolkema, M. P., Hess, D., Gelderblom, H., Hussain, S. A., Porro, M. G., Waldron, E., Valera, S. Z., Mu, S. 2015. «A phase I, open-label, multicenter study to evaluate the pharmacokinetics and safety of oral panobinostat in patients with advanced solid tumors and varying degrees of renal function». Cancer Chemotherapy and Pharmaco$\log y, \mathbf{7 5}, 87-95$.

[43] Galli, M., Salmoiraghi, S., Golay, J., Gozzini, A., Crippa, C., Pescosta, N., RambalDI, A. 2010. «A phase II multiple dose clinical trial of histone 
deacetylase inhibitor ITF2357 in patients with relapsed or progressive multiple myeloma». Annals of Hematology, 89, 185-190.

[44] Nilubol, N., Merkel, R., Yang, L., Patel, D., Reynolds, J. C., Sadowski, S. M., Neychev, V., Kebebew, E. 2017. «A phase II trial of valproic acid in patients with advanced, radioiodine-resistant thyroid cancers of follicular cell origin». Clinical Endocrinology, 86, 128-133.

[45] Bilen, M. A., Fu, S., Falchook, G. S., NG, C. S., Wheler, J. J., Abdelrahim, M., Erguvan-Dogan, B., Hong, D. S., Tsimberidou, A. M., KurZROCK, R., NAING, A. 2015. «Phase i trial of valproic acid and lenalidomide in patients with advanced cancer». Cancer Chemotherapy and Pharmacology, 75, 869-874.

[46] Suraweera, A., O’Byrne, K. J., Richard, D. J. 2018. «Combination therapy with histone deacetylase inhibitors (HDACi) for the treatment of cancer: Achieving the full therapeutic potential of HDACi». Frontiers in Oncology, 8, 1-15.

[47] Ramalingam, S. S., Parise, R. A., Ramananthan, R. K., Lagattuta, T. F., Musguire, L. A., Stoller, R. G., Potter, D. M., Argiris, A. E., ZwieBEL, J. A., EgORIN, M. J., BelANI, C. P. 2007. «Phase I and pharmacokinetic study of vorinostat, a histone deacetylase inhibitor, in combination with carboplatin and paclitaxel for advanced solid malignancies». Clinical Cancer Research, 13, 3605-3610.

[48] Marrocco, D. L., Tilley, W. D., Bianco-Miotto, T., Evdokiou, A., Scher, H. I., Rifkind, R. A., Marks, P. A., Richon, V. M., Butler, L. M. 2007. «Suberoylanilide hydroxamic acid (vorinostat) represses androgen receptor expression and acts synergistically with an androgen receptor antagonist to inhibit prostate cancer cell proliferation». Molecular Cancer Therapeutics, 6, 51-60.

[49] Buörkman, M., Iljin, K., Halonen, P., Sara, H., Kaivanto, E., NeEs, M., KALlioniemi, O. P. 2008. «Defining the molecular action of HDAC inhibitors and synergism with androgen deprivation in ERG-positive prostate cancer». International Journal of Cancer, 123, 2774-2781.

[50] Sharma, S., Taliyan, R. 2015. «Transcriptional dysregulation in Huntington's disease: The role of histone deacetylases». Pharmacological Research, 100, 157-169.

[51] Ganguly, S., SETH, S. 2018. «A translational perspective on histone acetylation modulators in psychiatric disorders». Psychopharmacology, 235, 18671873.

[52] Hogarth, P., Lovrecic, L., Krainc, D. 2007. «Sodium phenylbutyrate in Huntington's disease: A dose-finding study». Movement Disorders, 22, 1962-1964.

[53] Saft, C., Lauter, T., Kraus, P. H., Przuntek, H., Andrich, J. E. 2006. «Dose-dependent improvement of myoclonic hyperkinesia due to valproic acid in eight Huntington's Disease patients: A case series». BMC Neurology, 6, 1-6. 
[54] Unti, E., Mazzucchi, S., Kiferle, L., Bonuccelli, U., Ceravolo, R. 2012. «Q09 Valproic Acid for the treatment of aggressiveness in Huntington's disease: 1-year follow-up». Journal of Neurology, Neurosurgery \& Psychiatry, 83, A57.

[55] Reilmann, R., Squitieri, F., Priller, J., Saft, C., Mariotti, C., Sussmuth, S., Nemeth, A., Tabrizi, S., Quarrell, O., Craufurd, D., Rickards, H., Rosser, A., Darpo, B., Tessari, M., Szynol, A., FisCher, D., Frost, C., Farmer, R., Landwehrmeyer, G., Westerberg, G. 2014. «N02 Safety And Tolerability Of Selisistat For The Treatment Of Huntington's Disease: Results From A Randomised, Double-blind, Placebo-controlled Phase Ii Trial». Journal of Neurology, Neurosurgery \& Psychiatry, 85, A102.

[56] Peng, G. S., Li, G., Tzeng, N. S., Chen, P. S., Chuang, D. M., Hsu, Y. D., YANG, S., HONG, J. S. 2005. «Valproate pretreatment protects dopaminergic neurons from LPS-induced neurotoxicity in rat primary midbrain cultures: Role of microglia». Molecular Brain Research, 134, 162-169.

[57] KIDD, S. K., SCHNEIDER, J. S. 2011. «Protective effects of valproic acid on the nigrostriatal dopamine system in a 1-methyl-4-phenyl-1,2,3,6-tetrahydropyridine mouse model of Parkinson's disease». Neuroscience, 194, 189-194.

[58] Peedicayil, J. 2014. «Epigenetic approaches for bipolar disorder drug discovery». Expert Opinion on Drug Discovery, 9, 917-930.

[59] Phiel, C. J., Zhang, F., Huang, E. Y., Guenther, M. G., Lazar, M. A., KLEIN, P. S. 2001. «Histone Deacetylase is a Direct Target of Valproic Acid, a Potent Anticonvulsant, Mood Stabilizer, and Teratogen». Journal of Biological Chemistry, 276, 36734-36741.

[60] Machado-Vieira, R., Ibrahim, L., Zarate, C. A. 2011. «Histone Deacetylases and Mood Disorders: Epigenetic Programming in Gene-Environment Interactions». CNS Neuroscience and Therapeutics, 17, 699-704.

[61] RosenBerg, G. 2007. «The mechanisms of action of valproate in neuropsychiatric disorders: Can we see the forest for the trees?». Cellular and Molecular Life Sciences, 64, 2090-2103.

[62] Resende, W. R., Valvassori, S. S., Réus, G. Z., Varela, R. B., Arent, C. O., Ribeiro, K. F., Bavaresco, D. V., Andersen, M. L., Zugno, A. I., QueVEDOA, J. 2013. «Effects of sodium butyrate in animal models of mania and depression: Implications as a new mood stabilizer». Behavioural Pharmaco$\log y, 24,569-579$.

[63] Hasan, A., Mitchell, A., Schneider, A., Halene, T., Akbarian, S. 2013. «Epigenetic dysregulation in schizophrenia: Molecular and clinical aspects of histone deacetylase inhibitors». European Archives of Psychiatry and Clinical Neuroscience, 263, 273-284.

[64] Sajatovic, M., Coconcea, N., Ignacio, R. V., Blow, F. C., Hays, R. W., CASSIDY, K. A., MeYER, W. J. 2008. «Adjunct extended-release valproate semisodium in late life schizophrenia». International Journal of Geriatric Psychiatry, 23, 142-147. 
[65] Casey, D. E., Daniel, D. G., Wassef, A. A., Tracy, K. A., Wozniak, P., SommerviLLE, K. W. 2003. «Effect of divalproex combined with olanzapine or risperidone in patients with an acute exacerbation ofschizophrenia». Neuropsychopharmacology, 28, 182-192.

[66] Dincer, A., Gavin, D. P., Xu, K., Zhang, B., Dudley, J. T., Schadt, E. E., AKBARIAN, S. 2015. «Deciphering H3K4me3 broad domains associated with gene-regulatory networks and conserved epigenomic landscapes in the human brain». Translational Psychiatry, 5, E679.

[67] Kurita, M., Holloway, T., GarcÃ- A-Bea, A., Kozlenkov, A., Friedman, A. K., Moreno, J. L., Heshmati, M., Golden, S. A., Kennedy, P. J., TaKahashi, N., Dietz, D. M., Mocci, G., Gabilondo, A. M., Hanks, J., Umali, A., Callado, L. F., Gallitano, A. L., Neve, R. L., Shen, L., Buxbaum, J. D., Han, M. H., Nestler, E. J., Meana, J. J., Russo, S. J., GonzáLEZ-MAESO, J. 2012. «HDAC2 regulates atypical antipsychotic responses through the modulation of mGlu2 promoter activity». Nature Neuroscience, 15, 1245-1254. 
